\title{
Flavonoids from the Roots of Amomum compactum Soland Ex Maton (Zingiberaceae)
}

\author{
Deden Indra Dinata ${ }^{1,2}$, Rani Maharani ${ }^{2,3}$, Fauzan Zein Muttaqien ${ }_{5}^{1}$, Unang Supratman ${ }^{2,3 *}$ \\ Mohamad Nurul Azmi ${ }^{4}$, Yoshihito Shiono ${ }^{5}$ \\ ${ }^{1}$ Departemen of Pharmaceutical Analysis and Medicinal Chemistry, Faculty of Pharmacy, Bhakti Kencana \\ University, Soekarno Hatta 754, Bandung, 40286, Indonesia \\ ${ }^{2}$ Departemen of Chemistry, Faculty of Mathematics and Natural Sciences, Universitas Padjadjaran, Jatinangor, \\ 45363, Indonesia \\ ${ }^{3}$ Central Laboratory of Universitas Padjadjaran, Jatinangor 45363, Indonesia \\ ${ }^{4}$ School of Chemical Sciences, Universiti Sains Malaysia,11800 Minden,Penang, Malaysia \\ ${ }^{5}$ Departemen of Food, Life and Environmental Sciences, Yamagata University, Tsuruoka, 997-4555, Japan \\ *Corresponding author: unang.supratman@unpad.ac.id
}

Received: July 2021; Revision: July 2021; Accepted: September 2021; Available online: November 2021

\begin{abstract}
Amomum compactum Soland Ex Maton is one of the Zingiberaceae family plants which is the endemic plants from West Java, Indonesia. This study was aimed to determine the chemical structure of flavonoid compounds from $n$-hexane extract of A.compactum Sol. Ex Maton roots. Dried powder of the roots was extracted consecutively with $n$-hexane, ethyl acetate, and methanol solvents. Three flavonoids, 5-hydroxy-3,7,4'trimethoxy kaempferol (1), 5-hydroxy-3,7,3',4'-tetra methoxy kaempferol (2) and 4'-hydroxy-3,5,7-trimethoxy kaempferol (3), have been isolated from the roots of $A$. compactum Sol. Ex Maton. The chemical structures of compounds 1-3 were identified by spectroscopy data including infrared 1D-NMR, 2D-NMR and HRTOF-MS as well as by comparison with previously reported spectral data. Compounds 1-3 were isolated from this plant for the first time and showed free radical DPPH scavenging activity.
\end{abstract}

Keywords: Amomum compactum, antioxidant, DPPH, flavonoid, kaempferol

DOI: $10.15408 / j k v . v 7 i 2.21599$

\section{INTRODUCTION}

Amomum compactum Sol. Ex Maton one of the Amomum genera, belonging to the family Zingiberaceae, which has 53 species widely distributed in Asia and Australia with distribution centers in Southeast Asia (A. J. Droop \& Newman, 2014; J. Droop, Kaewsri, Lamxay, Poulsen, \& Newman, 2013; Lamxay, 2011). A. compactum is known as a cardamom in Indonesia and used as a cooking spice, health drink, traditional medicine and aromatherapy (Setyawan \& Bermawie, 2014). It was traditionally used in various gastrointestinal, cardiovascular and neural disorders (Aneja \& Joshi, 2009). The utilization of cardamom ( $A$. compactum) as cancer medicine has been reported by Deng (2012) in traditional Chinese medicine (Deng, Hu, \& An, 2012). The ethyl acetate soluble fraction of cardamom seeds
(Elettaria cardamomum) also showed antioxidant capacity with the ability to scavenge DPPH free radicals of $90 \%$ with the content of several phenolic compounds such as protocatecaldehyde and protocatechuic acid. Cardamom has also been demonstrated to decrease azoxymethane-induced colon carcinogenesis due to its antiinflammatory, antiproliferative, and proapoptotic activities (Bhagat \& Chaturvedi, 2016). The Aqueous suspension of cardamom (E. cardamomum) together with cinnamon (Cinnamomum burmani) was reported to increase detoxification enzyme activity (GST activity) and reduce lipid peroxidation that can induce colon cancer in Swiss Albino rats (Bhagat \& Chaturvedi, 2016; Bhattacharjee, Rana, \& Sengupta, 2007). The therapeutic potential of this spice plant is related to bioactive components such as alkaloids, 
terpenoids, flavonoids, phenylpropanoids including steroids (Bhagat and Chaturvedi, 2016; Md. Uzzal Haque, 2016). Besides, the components of the fruit of this plant are also known to have antioxidant activity (Zhang, Lu, \& Jiang, 2015). Studies have shown consistently that the antioxidant activity of phenolic compounds is reasonably related to their structure, namely, the substitutions on the aromatic rings and the structure of the side chain (Natella, Nardini, Di Felice, \& Scaccini, 1999). Recently much attention has focused on the role and mechanism of several flavonoids as inhibitors of oxidative processes in correlation with anticancer activity (Katayama et al., 2007) and antidiabetic (Sarian et al., 2017).

Due to its potential biological properties of flavonoids, the isolation of flavonoids from the Amomum compactum plant is of great interest. The first reported flavonoids isolated from the genus Amomum, namely fruits of A. tsaoko, were catechin and epicatechin. Both flavonoids reported to have strong antioxidant activity. The radical scavenging activity of the isolated compounds was evaluated using 2,2-diphenyl1-picrylhydrazyl (DPPH) and colorimetric and electron spin resonance (ESR) analyses (Martin, Kikuzaki, Hisamoto, \& Nakatani, 2000). Epicatechin has also been reported to have a neuroprotective activity (Zhang, Lu, \& Jiang, 2014). Meanwhile, quercetin, quercetin 3-Oglycoside and quercetin-7-O-glycoside, were also isolated from the genus and reported as neuroprotective agents similar to epicatechin (Zhang et al., 2014). However, all these studies at present on A. compactum plant have not been reported to detail chemical constitution analysis, and bioactivity studies were restricted to its crude extracts. In our continuous effort to discover interesting molecules from the Amomum plant, this study revealed the presence of flavonoid compounds from A.compactum Sol. Ex Maton. Although the compounds have been previously reported by Cornelius et al. (2010) (Cornelius et al., 2010) these secondary metabolites in A.compactum Sol. Ex Maton. has not been reported yet.

\section{MATERIALS AND METHODS}

The experimental section including general experimental procedur, plant material, plant extraction and isolation, and antioxidant activity assays (DPPH radicals scavenging activity).

\section{General Experimental Procedures}

The Fourier transform infrared (FTIR) spectra were recorded on a Thermo Scientific. The mass spectra were recorded with a Waters Xevo High Resolution Top of Flight Mass Spectrometry (HRTOF-MS). Nucleic magnetic resonance (NMR) Data were recorded on the Bruker Top Spin spectrometer at $500 \mathrm{MHz}$ and JEOL ECZR $600 \mathrm{MHz}$ for 1D and 2D NMR using TMS as an internal standard. Column chromatography was conducted on silica gel 60, 200-400 Mesh (Merck, and Kanto Chemical). Thin layer chromatography (TLC) plates were precoated with silica gel $\mathrm{GF}_{254}$ (Merck, $0.25 \mathrm{~mm}$ ) and detection was achieved by spraying with $10 \% \mathrm{H}_{2} \mathrm{~S}_{4}$ in ethanol and also using $\mathrm{AlCl}_{3}$ in $10 \%$ ethanol, following by observing under ultraviolet light at wavelength $254 \mathrm{~nm}$ and $367 \mathrm{~nm}$, and also by heating respectively.

\section{Plant Material}

The roots of $A$. compactum Soland Ex Maton was collected from community cultivation in Garut Regency, West Java, Indonesia. The plant was determined at the Laboratory of Taxonomy of Biology, Universitas Padjadjaran, Indonesia The sample (No.466 HB) has been deposited at the herbarium.

\section{Plant Extraction and Isolations}

Cardamom dried root (A. compactum Soland Ex Maton) $(5.4 \mathrm{~kg}$ ) was macerated with 20 L $96 \%$ ethanol for $2 \times 24$ hours repeatedly at room temperature, then the combined macerate was concentrated with a rotary evaporator. The ethanolic extracts was obtained for $142.5 \mathrm{~g}$. The extracts was dissolved with distilled water and partitioned sequentially with $n$-hexane, ethyl acetate and $n$-butanol then each organic fraction was concentrated to obtain crude extracts of $n$-hexane (38.85 g), ethyl acetate (14.40 g), $n$-butanol (44.35), and water (26.32 g). Each extract was tested for its free radical DPPH scavenging activity. The $n$-hexane extract was then fractionated by vacuum liquid chromatography (silica gel $\mathrm{G}_{60}$ ) with the solvent of a mixture of $n$-hexane, ethyl acetate and methanol with a polarity increase of $20 \%$ to obtain 10 fractions (A-J) that were combined according to TLC analysis. Fraction D (3.2 g) was then separated by column chromatography on silica gel using a gradient of $n$-hexane-ethyl acetate-methanol with a $5 \%$ stepwise polarity 
increase to produce 15 subfractions $\left(D_{1}-D_{15}\right)$. $\mathrm{D}_{12}$ fraction $(155.2 \mathrm{mg})$ was subjected to column chromatography on silica gel using $n$ hexane-ethyl acetate and methanol, with a 5\% stepwise polarity increase to afford 7 subfractions $\left(\mathrm{D}_{12} \mathrm{~A}-\mathrm{D}_{12} \mathrm{~F}\right)$. Subfraction $\mathrm{D}_{12}$. B (120.6 mg) was column chromatographed on ODS, eluted with methanol: $\mathrm{H}_{2} \mathrm{O}(9: 1)$ to give $1(71.3 \mathrm{mg})$. Fraction E (1.9 g) was subjected to column chromatography on silica gel with $5 \%$ gradient of $n$-hexane-ethyl acetatemethanol to result in 13 subfractions $\left(E_{1}-E_{13}\right)$. Subfraction $\mathrm{E}_{4}(45.8 \mathrm{mg})$ was then separated by column chromatography on silica gel using $n$-hexane-dichloromethane-ethyl acetate (7.5:4.5:3) to give combined subfraction 5 subfraction (E4A-E4E). Subfraction E E.D (14.9 $\mathrm{mg}$ ), further column chromatographed on ODS using methanol-water (8:2) and obtained 2 (2.2 $\mathrm{mg})$. Fraction $\mathrm{G}(1.0 \mathrm{~g})$ was separated by column chromatography on silica gel using a gradient mixture of $n$-hexane-ethyl acetatemethanol to result in 13 fractions. Fraction $\mathrm{G}_{5}$ (35 mg) was subjected on a column chromatography on silica gel using $\mathrm{CHCl}_{3}-$ ethyl acetate-methanol to afford 13 subfractions. Subfraction $\mathrm{G}_{5} \mathrm{~B}(15 \mathrm{mg})$ further separated by preparative TLC on silica gel $\mathrm{GF}_{254}$ with $\mathrm{CHCl}_{3}$ as a solvent to give 3 (2.0 $\mathrm{mg})$.

\section{Antioxidant Activity Assays (DPPH Radicals Scavenging Activity)}

The DPPH radical-scavenging activity was estimated by the method of Schreiber, Bozell, Hayes, and Zivanovic (2013) with some modifications (Schreiber, Bozell, Hayes, \& Zivanovic, 2013; Zhang et al., 2015). Briefly, the various fractions and three compounds obtained from A. compactum were dissolved in methanol to form a sample solution in a series of concentrations. The DPPH stock solution $(50 \mathrm{mg} / \mathrm{mL})$ was diluted with methanol to an absorbance of 1.0 at 517 $\mathrm{nm}$ before $3 \mathrm{~mL}$ of the diluted DPPH solution were mixed with $1 \mathrm{~mL}$ of various concentrations of the sample. The reaction mixture was shaken well and incubated for 30 min at room temperature in the dark. The absorbance of the resulting solution was read with a spectrophotometer at $517 \mathrm{~nm}$ against a blank. Lower absorbance of the reaction mixture indicates higher free radicalscavenging activity. The radical scavenging activity of DPPH was calculated according to the following equation:

Scavenging activity $(\%)=\frac{A o-A 1}{A 0} \times 100$

where $A_{0}$ is the absorbance of the DPPH radical solution without sample and $A_{1}$ is the absorbance of the DPPH radical solution with tested samples. Ascorbic acid was used as a reference compound (Kassim et al., 2013; Molyneux P, 2004).

\section{RESULTS AND DISCUSSION}

At the initial stage, the dried root of $A$. compactum Sol. Ex Maton was macerated with ethanol and the combined macerates were concentrated to give a crude extract. The ethanol extract was partitioned with $n$-hexane, ethyl acetate, $n$-butanol and water then tested for its free radical scavenging activity using the DPPH method to give of $\mathrm{IC}_{50}$ values of 147.93 , $1185.98,60.04,58.48$ and $1999.66 \mathrm{mg} / \mathrm{mL}$, respectively. Referring to Blois (1958) in (Molyneux P, 2004), extracts with an $\mathrm{IC}_{50}$ value $<50 \mu \mathrm{g} / \mathrm{mL}$ are considered as very strong antioxidant activity, whereas an $\mathrm{IC}_{50}$ value $>200 \mu \mathrm{g} / \mathrm{mL}$ is considered as very weak. As a continuing study in the search of flavonoid compounds, from the $n$-hexane fraction was chromatographed over vacuumliquid chromatography (VLC) and silica gel column chromatography to afford compounds 1, 2, and 3. The three compounds showed similarities from the TLC analysis, which were yellow sprayed with $10 \% \mathrm{H}_{2} \mathrm{SO}_{4}$ reagent and also $\mathrm{AlCl}_{3}$ in ethanol, each of which was followed by heating indicated that compounds 1-3 have conjugated double bonds. The all three ultraviolet spectrums showed the presence of two absorption bands of the cinnamoil and benzoyl rings, which are typical for flavonoid compounds with flavone skeletons (Markham, 2007). The all three infrared spectrums showed the presence of an absorption band that confirmed the presence of aliphatic $\mathrm{CH}$ stretch, the double bond of the aromatic ring assisted by absorption in the fingerprint region, then the presence of conjugated carbonyl and ether. The structure of the compounds was analysed using spectroscopic data including FTIR, 1D and 2D NMR as well as HRTOF-MS (Figure 1). 
<smiles>COc1ccc(-c2oc3cc(OC)cc(O)c3c(=O)c2OC)cc1</smiles>

(1)<smiles>COc1cc(O)c2c(=O)c(OC)c(-c3ccc(OC)c(OC)c3)oc2c1</smiles>

(2)<smiles>COc1cc(OC)c2c(=O)c(OC)c(-c3ccc(O)cc3)oc2c1</smiles>

(3)

Figure 1. Structure of compounds 1, 2 and $\mathbf{3}$

The DPPH assay has been widely used to measure radical scavengers because it is stable, and the reaction system covers only direct reactions between radicals and antioxidants (Kassim et al., 2013). The DPPH radical exhibits a strong maximum absorption at $517 \mathrm{~nm}$, resulting in a purple color (Bellik et al., 2013). When a solution of DPPH (radical form) is mixed with a substance that can donate a hydrogen atom, then this gives the reduced form (unradical) with the disappearance of this purple color (although there will be expected to be a pale yellow remnant of extant picryl groups (Molyneux P, 2004).

\section{5-hydroxy-3, 7,4'-trimethoxy}

kaempferol (1). Yellow amorphous crystalline; melting point $145.5^{\circ} \mathrm{C}$; UV $\lambda_{\max } 254$ and 365 $\mathrm{nm}$; IR (FTIR) $v_{\max }\left(\mathrm{cm}^{-1}\right) 2847,1655,1582$, 1000, 742; ${ }^{1} \mathrm{H}$ NMR $\left(\mathrm{CDCl}_{3}, 500 \mathrm{MHz}\right) ;{ }^{13} \mathrm{C}$ NMR $\left(\mathrm{CDCl}_{3}, 125 \mathrm{MHz}\right)$ see Table 1;

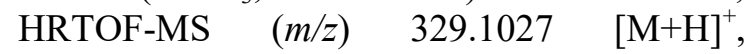
calculation for $\mathrm{C}_{18} \mathrm{H}_{16} \mathrm{O}_{6}(\mathrm{~m} / \mathrm{z}) 328.1025$.

5-hydroxy-3,7,3',4'-tetramethoxy

kaempferol (2). Yellow amorphous crystals; melting point $140^{\circ} \mathrm{C}$; UV $\lambda_{\max } 243 \mathrm{~nm}$ and 350 $\mathrm{nm}$; IR (FTIR) $v_{\max }\left(\mathrm{cm}^{-1}\right): 2922,2851,1734$, 1648, 1125 and 935; ${ }^{1} \mathrm{H}-\mathrm{NMR}\left(\mathrm{CDCl}_{3}, 500\right.$ MHz) $\delta_{\mathrm{H}}(\mathrm{ppm}) ;{ }^{13} \mathrm{C}-\mathrm{NMR}\left(\mathrm{CDCl}_{3}, 125 \mathrm{MHz}\right)$ $\delta_{\mathrm{C}}(\mathrm{ppm})$ see Table 1 ; HRTOF-MS $(\mathrm{m} / \mathrm{z})$ $359.1137[\mathrm{M}+\mathrm{H}]^{+}$, calculation for $\mathrm{C}_{19} \mathrm{H}_{19} \mathrm{O}_{7}$, $(\mathrm{m} / \mathrm{z}) 359,1131$.

4'-hydroxy-3,5,7-trimethoxy

kaempferol (3). Yellow amorphous crystalline; melting point $143^{\circ} \mathrm{C} ; \lambda_{\max } 283$ and $348 \mathrm{~nm}$; IR (FTIR) $v_{\max }\left(\mathrm{cm}^{-1}\right) 2920,1655,1582,1216$, 768; ${ }^{1} \mathrm{H}$ NMR $\left(\mathrm{CDCl}_{3}, 600 \mathrm{MHz}\right) ;{ }^{13} \mathrm{C}$ NMR $\left(\mathrm{CDCl}_{3}, 150 \mathrm{MHz}\right)$ see Table 1; HRTOF-MS $(\mathrm{m} / z) \quad 329.1039 \quad[\mathrm{M}+\mathrm{Na}]^{+}$, calculation for $\mathrm{C}_{18} \mathrm{H}_{16} 0_{5}(\mathrm{~m} / \mathrm{z}) 329.1025$.

Compound (1) was obtained as a yellow amorphous crystalline. HRTOF-MS spectrum of $\mathbf{1}$ showed $\left([\mathrm{M}+\mathrm{H}]^{+} \mathrm{m} / z 329.1027\right.$ (calcld. $m / z$ 328.1025), which corresponds to the molecular formula of $\mathrm{C}_{18} \mathrm{H}_{16} \mathrm{O}_{6}$ thus providing eleven degrees of unsaturation. UV spectra in methanol showed $\lambda_{\max } 283$ and 348 $\mathrm{nm}$ indicated the presence of flavon skeleton (Marby, TJ, Markam, K.R.and Thomas, 1970; Markham, 2007). The IR spectra showed the peaks at $v_{\max }\left(\mathrm{cm}^{-1}\right) 2847,1655,1582,1000$, 742 indicating the presence of hydroxyl groups, $\mathrm{C}=\mathrm{C}$ aromatics, symmetric and asymmetric of $\mathrm{C}-\mathrm{O}-\mathrm{C}, \mathrm{C}=\mathrm{O}$, and substituted benzene ring, respectively. The ${ }^{1} \mathrm{H}-\mathrm{NMR}$ spectrum of compound $\mathbf{1}$ showed the presence of six olefinic methine protons consisted of two protons resonating at $\delta_{\mathrm{H}} 6.33$ and 6.42 ppm (each $1 \mathrm{H}, d, J=2.2 \mathrm{~Hz}$ ) that were assigned for $\mathrm{H}-6$ and $\mathrm{H}-8$ in A ring. Two pairs of methine protons resonating at $\delta_{\mathrm{H}} 8.05$ (each $1 \mathrm{H}, d d, J=9.1,2.9 \mathrm{~Hz}, \mathrm{H}-2^{\prime}$ and H-6') and the others at $\delta_{\mathrm{H}} 7.00$ (each $1 \mathrm{H}, d d, J=9.0,2.9 \mathrm{~Hz}$, $\mathrm{H}-3^{\prime}$ and $\mathrm{H}-5^{\prime}$ ) were assigned to be $\mathrm{ABC}$ proton type in $\mathrm{B}$ ring. The spectrum also showed the presence of 3 oxygenated methyl protons at $\delta_{\mathrm{H}}$ $3.83\left(3 \mathrm{H}, s, 3-\mathrm{OCH}_{3}\right), 3.85\left(3 \mathrm{H}, s, 7-\mathrm{OCH}_{3}\right)$, and $3.87\left(3 \mathrm{H}, s, 4{ }^{\prime}-\mathrm{OCH}_{3}\right)$. Compound 1 also showed the presence of a hydroxyl proton resonating at $\delta_{\mathrm{H}} 12.63(1 \mathrm{H}, s)$, which was attached to C-5. Two meta-protons at ring A evidenced by the $J$ coupling constant of H-6 and $\mathrm{H}-8$ as $2.2 \mathrm{~Hz}$ and by $\mathrm{HMBC}$ correlation between $\mathrm{H}-6$ to $\mathrm{C}-5, \mathrm{C}-7$, and $\mathrm{H}-8$ to $\mathrm{C}-7$ and C-9 (Figure 2). A $p$-substituted benzene of $\mathrm{C}$ ring observed at $\delta_{\mathrm{H}} 8.05$ (each $1 \mathrm{H}, d d$, $J=9.1,2.9 \mathrm{~Hz}, \mathrm{H}-2^{\prime}$ and $\mathrm{H}-6^{\prime}$ ) and the others at $\delta_{\mathrm{H}} 7.00\left(\right.$ each $1 \mathrm{H}, d d, J=9.0,2.9 \mathrm{~Hz}, \mathrm{H}-3^{\prime}$ and $\left.\mathrm{H}-5^{\prime}\right)$ were supported by ${ }^{1} \mathrm{H}-{ }^{1} \mathrm{H}-\mathrm{COSY}$ cross peak $\mathrm{H}-2^{\prime} / \mathrm{H}-3^{\prime}$ and $\mathrm{H}-5^{\prime} / \mathrm{H}-6$ ' (Figure 2). The flavonol skeleton in ring $\mathrm{C}$ was evidenced by the presence of quaternary carbon at $\delta_{\mathrm{C}} 139.0$ ppm (C-3) and 178.9 (C-4) and through $\mathrm{HMBC}$ correlation between $\delta_{\mathrm{H}} 3.83\left(3-\mathrm{OCH}_{3}\right)$ to $\delta_{\mathrm{C}} 139.0(\mathrm{C}-3)$. The ${ }^{13} \mathrm{C}$ NMR and DEPT 
$135^{0}$ spectra of the compound showed the presence of six olefinic methines and six quaternary olefinic carbon (12 $s p^{2}$ carbons), three methoxy carbons, $\mathrm{C}=\mathrm{C}$ aromatic ring and one ketone carbon. These functionalities accounted for eight of the total eleven degrees of unsaturation, and the remaining three degrees of unsaturation were consistent with the flavonol structure. Detailed comparison of NMR spectra of 1 to those of reported 3,7,4'trimethoxy kaempferol (Cornelius et al., 2010; Rossi, Yoshida, \& Maia, 1997), revealed that the structure was very similar, consequently, compound $\mathbf{1}$ was identified as 5-hydroxy3,7,4'-trimethoxy kaempferol.

Compound 2 was obtained as colorless needle crystals. HRTOF-MS $(\mathrm{m} / \mathrm{z}) \quad 359.1137$ $[\mathrm{M}+\mathrm{H}]^{+}$, calculation for $\mathrm{C}_{19} \mathrm{H}_{19} \mathrm{O}_{7},(\mathrm{~m} / \mathrm{z}) 359,1131$, required twelve unsaturation. IR (FTIR) $v_{\max } \mathrm{cm}^{-1}$ : 2922 (C-H aliphatic), 2851 (C-H sp $\left.p^{3}\right), 1734(\mathrm{C}=\mathrm{O})$, $1648(\mathrm{C}=\mathrm{C}$ aromatic), 1125 (asymmetric $\mathrm{C}-\mathrm{O}-\mathrm{C}$ stretch and 935 (substituted benzene ring). The NMR spectra were very similar to those of compound 1 except for the addition of methoxy at C-3'. The methoxy substituent at C-3' as shown in Figure 2, confirmed on compound $\mathbf{2}$ by key HMBC correlation between $\delta_{\mathrm{H}} 7.75\left(\mathrm{H}-2^{\prime}\right)$ and $\delta_{\mathrm{H}} 3.95\left(3^{\prime}-\right.$ $\left.\mathrm{OCH}_{3}\right)$ to $\delta_{\mathrm{C}} 111.2\left(\mathrm{C}-3^{\prime}\right)$.

Compound $\mathbf{3}$ was obtained as a yellow amorphous powder. HRTOF-MS spectrum of $\mathbf{3}$ showed $[\mathrm{M}+\mathrm{Na}]^{+} \quad m / z \quad 329.1039 \quad[\mathrm{M}+\mathrm{Na}]^{+}$ (calcld. $(\mathrm{m} / \mathrm{z}) 329.1025$, which corresponded to the molecular formula of $\mathrm{C}_{18} \mathrm{H}_{16} \mathrm{O}_{5}$ thus providing eleven degrees of unsaturation. UV spectrum of $3(\mathrm{MeOH}) \lambda_{\max } 283$ and $348 \mathrm{~nm}$. IR spectrum showed absorption band at 2920 $\mathrm{cm}^{-1}$ (C-H stretch), $1655 \mathrm{~cm}^{-1}(\mathrm{C}=\mathrm{C}$ aromatic stretch), $1582 \mathrm{~cm}^{-1}$ (symmetric C-O-C), 1216 $\mathrm{cm}^{-1}$ (asymmetric C-O-C stretch) and $768 \mathrm{~cm}^{-1}$ (substituted benzene ring). The NMR spectra were very similar to those of compound $\mathbf{1}$ except for the absence of proton hydroxyl at C5. Detailed comparison of NMR spectra of $\mathbf{3}$ to those of 3,7,4'-trimethoxy kaempferol (Rossi et al., 1997) was very similar except for 5hydroxy compare to (Cornelius et al., 2010) it's substituted to methoxy as shown at Figure 2 there was HMBC correlation between $\delta_{\mathrm{H}} 3.88$ $\left(5-\mathrm{OCH}_{3}\right)$ to $\delta_{\mathrm{C}} 161.9(\mathrm{C}-5)$. Meanwhile, the 4'hydroxy evidenced by HMBC correlation $\delta_{\mathrm{H}}$ $7.69\left(\mathrm{H}-5{ }^{\prime}\right)$ and $\delta_{\mathrm{H}} 6.97(\mathrm{H}-6 ')$ to $\delta_{\mathrm{C}} 146.2(\mathrm{C}-$ 4 ), consequently, compound 3 was identified as 4'-hydroxy-3,5,7-trimethoxy kaempferol.
Different chemical constituents are isolated of $A$. compactum and compounds 1-3 were tested for their antioxidant capacity using DPPH free radical scavenging test. Compound 1 exhibited the highest scavenging activity at $23.47 \%$ while the other at $8.16 \%$ (2) and $3.87 \%$ (3), respectively. The antioxidant activities of the compounds 1-3 were lower compared to kaempferol with scavenging activity at $65.3 \%$; due to the presence of methoxy substituents whether than phenolic hydroxyl groups (Burda \& Oleszek, 2001). The role of flavonoids as antioxidants related to the number of hydroxyl groups in combination with the conjugated p-electron system, allowing them to act as free radical scavengers via hydrogen atom or electron donation (Martinez-Perez et al., 2014). Generally, position and number of hydroxylation correlate reasonably to the anti-oxidation activity of flavonoids. Compound $\mathbf{2}$ with 4 methoxy groups and compounds $1 \& \mathbf{3}$ with 3 methoxy groups showed low DPPH radical scavenging activity, it's consistent with the structureactivity relationship study of flavonoid compounds, noticed that the premise of at least two hydroxyl groups in ring B for anti-oxidant capacity is suggested based on significantly improved anti-oxidant effects (Wang, Li, \& Bi, 2018)

Hydrogens and electrons are donated by ring B hydroxyl groups to hydroxyl, peroxyl, and peroxyl nitrite radicals, forming relatively stable flavonoid radicals. Due to reducing activities of phenolic hydroxyl groups, flavonoids are able to donate hydrogen. Along with delocalization of phenoxy radical products, flavonoids can protect against various disease damage from ROS. On the other side, flavonoids could scavenge the resulting radicals to neutralize the prior effect (Verma et al., 2012). The structure activity relationship of flavonoid compound from the roots of A. compactum Sol. Ex Maton was as follows: (a) the presence of hydroxyl in ring $\mathrm{A}$ (5-OH and 7-OH) increases activity, and loss of it decreases activity; (b) The loss of two Ortho 3',4' hydroxyl in ring B decreases activity; (c) $\mathrm{C}=\mathrm{C}$ bonds at $\mathrm{C}-2$ \& $\mathrm{C}-3$, 4-keto $(\mathrm{C}=\mathrm{O})$ and $3-\mathrm{OH}$ in ring $\mathrm{C}$ increase activity, substitution of $3-\mathrm{OCH}_{3}$ decreases activity. 


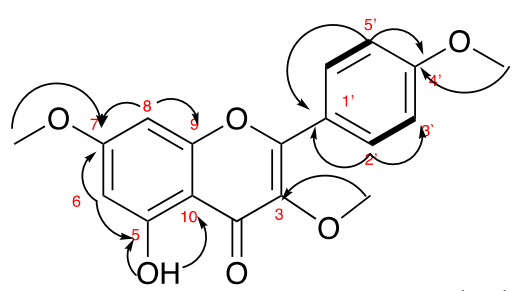

(1)

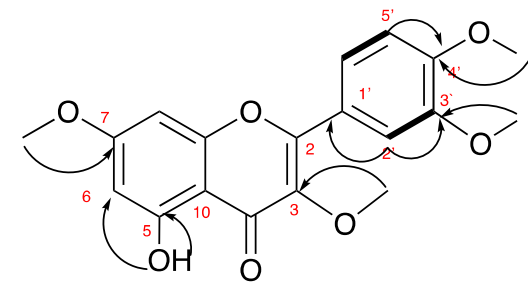

(2)

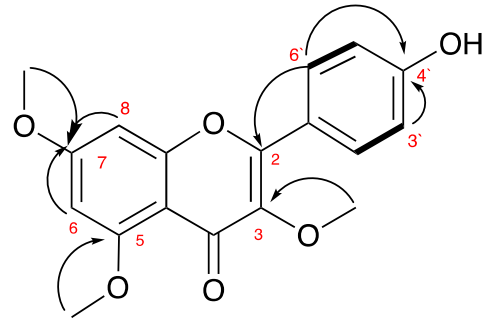

(3)

Figure 2. Key HMBC and ${ }^{1} \mathrm{H}-{ }^{1} \mathrm{H}-\mathrm{COSY}$ correlation of compound 1-3

Table 2. NMR Data of Compounds 1-3, $\delta$ in ppm, $J$ in $\mathrm{Hz}$

\begin{tabular}{|c|c|c|c|c|c|c|}
\hline & $\delta_{\mathrm{C}}$ & $\delta_{\mathrm{H}}(\Sigma \mathrm{H}$, mult. $J)$ & $\delta_{\mathrm{C}}$ & $\delta_{\mathrm{H}}\left(\sum \mathrm{H}\right.$, mult. $\left.J\right)$ & $\delta_{\mathrm{C}}$ & $\delta_{\mathrm{H}}\left(\sum H\right.$, mult. $\left.J\right)$ \\
\hline Positions & & $(1)^{\mathrm{a}}$ & & $(2)^{b}$ & & $(3)^{a}$ \\
\hline 2 & 156.1 & & 143.2 & & 153.2 & - \\
\hline 3 & 139.0 & & 138.8 & & 138.8 & - \\
\hline 4 & 178.9 & & 176.9 & & 179.0 & - \\
\hline 5 & 161.8 & & 161.5 & - & 161.9 & - \\
\hline 6 & 98.0 & $6.33(1 \mathrm{H} ; d ; 2.2)$ & 97.8 & $6.35(1 \mathrm{H} ; d ; 2.0)$ & 97.8 & $6.35(1 \mathrm{H}, d, 2.2)$ \\
\hline 7 & 165.5 & & 165.4 & & 165.8 & - \\
\hline 8 & 92.3 & $6.42(1 \mathrm{H} ; d ; 2.2)$ & 92.1 & $6.43(1 \mathrm{H} ; d ; 2.0)$ & 92.1 & $6.44(1 \mathrm{H}, d, 2.2)$ \\
\hline 9 & 156.9 & & 151.5 & & 156.7 & - \\
\hline 10 & 106.2 & & 102.5 & & 106.0 & - \\
\hline 1 & 123.0 & & 122.2 & & 122.8 & - \\
\hline 2 & 130.3 & $\begin{array}{c}8.05(1 \mathrm{H} ; d d ; 9.1, \\
2.9)\end{array}$ & 122.1 & $\begin{array}{c}7.75(1 \mathrm{H} ; \\
d d ; 2.0,8.5)\end{array}$ & 130.1 & $8.07(1 \mathrm{H}, d, 9.0)$ \\
\hline 3 & 114.2 & $\begin{array}{c}7.00(1 \mathrm{H} ; d d ; 9.0 \\
2.9)\end{array}$ & 111.2 & - & 114.0 & $7.02(1 \mathrm{H}, d, 9.0)$ \\
\hline 4 & 162.2 & & 146.2 & - & 161.6 & - \\
\hline 5 & 114.2 & $\begin{array}{c}7.00(1 \mathrm{H} ; d d ; 9.0, \\
2.9)\end{array}$ & 132.2 & $7.69(1 \mathrm{H} ; d ; 2.0)$ & 114.0 & $7.02(1 \mathrm{H}, d, 9.0)$ \\
\hline 6 & 130.3 & $\begin{array}{c}8.05(1 \mathrm{H} ; d d ; 9.1, \\
2.9)\end{array}$ & 111.7 & $6.97(1 \mathrm{H} ; d ; 9.0)$ & 130.1 & $8.07(1 \mathrm{H}, d, 9.0)$ \\
\hline $3-\mathrm{OCH}_{3}$ & 55.6 & $3.83(3 \mathrm{H} ; s)$ & 60.3 & $3.84(3 \mathrm{H} ; s)$ & 55.4 & $3.90(3 \mathrm{H}, s)$ \\
\hline $\begin{array}{l}5-\mathrm{OCH}_{3} \\
7-\mathrm{OCH}_{3}\end{array}$ & 56.0 & $3.85(3 \mathrm{H} ; s)$ & 55.9 & $3.85(3 \mathrm{H} ; s)$ & $\begin{array}{l}60.1 \\
55.8\end{array}$ & $\begin{array}{l}3.88(3 \mathrm{H}, s) \\
3.84(3 \mathrm{H}, s)\end{array}$ \\
\hline 3'- $-\mathrm{OCH}_{3}$ & & & 56.1 & $3.95(3 \mathrm{H} ; d, 2.2)$ & & \\
\hline $4-\mathrm{OCH}_{3}$ & 60.3 & $3.87(3 \mathrm{H} ; s)$ & 60.2 & $3.94(3 \mathrm{H} ; d, 2.2)$ & & \\
\hline $5-\mathrm{OH}$ & - & $12.63(1 \mathrm{H}, s)$ & - & $12.63(1 \mathrm{H}, s)$ & - & $12.60(1 \mathrm{H}, \mathrm{s})$ \\
\hline
\end{tabular}

${ }^{\mathrm{a} 1} \mathrm{H}-\mathrm{NMR}(500 \mathrm{MHz}),{ }^{13} \mathrm{C}-\mathrm{NMR}(125 \mathrm{MHz})$, in $\mathrm{CDCl}_{3}$

${ }^{\text {b } 1} \mathrm{H}-\mathrm{NMR}$ (600 MHz), ${ }^{13} \mathrm{C}-\mathrm{NMR}(150 \mathrm{MHz})$, in $\mathrm{CDCl}_{3}$

These flavonoid compounds, 5hydroxy-3,7,4'-trimethoxy kaempferol (1), 5hydroxy-3,7,3',4'-tetramethoxy kaempferol (2) and 4'-hydroxy-3,5,7-trimetoxy kaempferol (3) were isolated in this plant for the first time and support also the presence of flavonoid compound in the Amomum genus beside other metabolites compounds as a chemical marker. The antioxidant capacity correlated with the position and number of hydroxylation of the flavonoid compounds.

\section{CONCLUSION}

Three flavonoid compounds, 5hydroxy-3,7,4'-trimethoxy kaempferol (1), 5hydroxy-3,7,3',4'-tetra methoxy kaempferol (2) and 4'-hydroxy-3,5,7-trimethoxy kaempferol (3) have been isolated from the roots of Amomum compactum Soland Ex Maton. These compounds were isolated from this plant for the first time and having free radical DPPH scavenging activity.These findings support efforts to develop natural antioxidant 
compounds as lead compounds for the development of degenerative disease drugs.

\section{ACKNOWLEDGMENT}

This research was financially supported by the Directorate General of Higher Education, Ministry of Science, Technology and Higher Education, Indonesia in the scheme of Doctoral Dissertation Research Grant (PDD) and also supported by Institute for Research and Community Service, Bhakti Kencana University, Bandung, Indonesia.

\section{REFERENCES}

Aneja, K. R., \& Joshi, R. (2009). Antimicrobial Activity of Amomum subulatum and Elettaria cardamomum Against Dental Caries Causing Microorganisms. 93(4), 136119.

Bellik, Y., Benabdesselam, F., Ayad, A., Dahmani, Z., Boukraa, L., Nemmar, A., \& IguerOuada, M. (2013). Antioxidant activity of the essential oil and oleoresin of zingiber officinale roscoe as affected by chemical environment. International Journal of Food Properties, 16(6), 1304-1313. https://doi.org/10.1080/10942912.2011.58 4257

Bhagat, N., \& Chaturvedi, A. (2016). Spices as an alternative therapy for cancer treatment. Systematic Reviews in Pharmacy, 7(1), $46-56$.

https://doi.org/10.5530/srp.2016.7.7

Bhattacharjee, S., Rana, T., \& Sengupta, A. (2007). Inhibition of lipid peroxidation and enhancement of GST activity by cardamom and cinnamon during chemically induced colon carcinogenesis in Swiss albino mice. Asian Pacific Journal of Cancer Prevention, 8(4), 578582.

Burda, S., \& Oleszek, W. (2001). Antioxidant and antiradical activities of flavonoids. Journal of Agricultural and Food Chemistry, 49(6), 2774-2779. https://doi.org/10.1021/jf001413m

Cornelius, M. T. F., De Carvalho, M. G., Da Silva, T. M. S., Alves, C. C. F., Siston, A. P. N., Alves, K. Z., ... Braz-Filho, R. (2010). Other chemical constituents isolated from Solanum crinitum Lam. (Solanaceae). Journal of the Brazilian Chemical Society, 2l(12), 2211-2219.
https://doi.org/10.1590/S0103-

50532010001200007

Deng, S., Hu, B., \& An, H.-M. (2012). Traditional Chinese Medicinal Syndromes and Treatment in Colorectal Cancer. Journal of Cancer Therapy, 03(06), 888-897. https://doi.org/10.4236/jct.2012.326114

Droop, A. J., \& Newman, M. F. (2014). A revision of amomum (zingiberaceae) in sumatra. Edinburgh Journal of Botany, 71(2), 193258.

https://doi.org/10.1017/S09604286140000 43

Droop, J., Kaewsri, W., Lamxay, V., Poulsen, A. D., \& Newman, M. (2013). Identity and lectotypification of Amomum compactum and Amomum kepulaga (Zingiberaceae). Taxon, 62(6), 1287-1294. https://doi.org/10.12705/626.8

Kassim, N. K., Rahmani, M., Ismail, A., Sukari, M. A., Ee, G. C. L., Nasir, N. M., \& Awang, K. (2013). Antioxidant activity-guided separation of coumarins and lignan from Melicope glabra (Rutaceae). Food Chemistry, 139(1-4), 87-92. https://doi.org/10.1016/j.foodchem.2013.0 1.108

Katayama, K., Masuyama, K., Yoshioka, S., Hasegawa, H., Mitsuhashi, J., \& Sugimoto, Y. (2007). Flavonoids inhibit breast cancer resistance protein-mediated drug resistance: Transporter specificity and structure-activity relationship. Cancer Chemotherapy and Pharmacology, 60(6), 789-797. https://doi.org/10.1007/s00280007-0426-7

Lamxay. (2011). The Genus Amomum (Zingiberaceae) in Cambodia, Laos and Vietnam. Acta Universitatis Upsaliensis UPPSALA, 53(9), 1689-1699.

Marby, TJ, Markam, K.R.and Thomas, M. . (1970). The Systematic Identification of Flavonoids. Springer-Verlag.

Markham, Ø. M. A. and K. R. (2007). Flavonoids, Chemistry, Biochemistry and Applications. 119(50), 140-141.

Martin, T. S., Kikuzaki, H., Hisamoto, M., \& Nakatani, N. (2000). Constituents of Amomum tsao-ko and their radical scavenging and antioxidant activities. JAOCS, Journal of the American Oil 
Chemists' Society, 77(6), 667-673. https://doi.org/10.1007/s11746-000-0107-4

Martinez-Perez, C., Ward, C., Cook, G., Mullen, P., McPhail, D., Harrison, D. J., \& Langdon, S. P. (2014). Novel flavonoids as anticancer agents: Mechanisms of action and promise for their potential application in breast cancer. Biochemical Society Transactions, 42(4), 1017-1023. https://doi.org/10.1042/BST20140073

Molyneux P. (2004). The use of the stable free radical diphenylpicryl-hydrazyl (DPPH) for estimating anti-oxidant activity. Songklanakarin Journal of Science and Technology, 26(May), 211-219.

Natella, F., Nardini, M., Di Felice, M., \& Scaccini, C. (1999). Benzoic and cinnamic acid derivatives as antioxidants: Structureactivity relation. Journal of Agricultural and Food Chemistry, 47(4), 1453-1459. https://doi.org/10.1021/jf980737w

Rossi, M. H., Yoshida, M., \& Maia, J. G. S. (1997). Neolignans, styrylpyrones and flavonoids from an Aniba species. Phytochemistry, 45(6), 1263-1269. https://doi.org/10.1016/S00319422(97)00075-7

Sarian, M. N., Ahmed, Q. U., Mat So'Ad, S. Z., Alhassan, A. M., Murugesu, S., Perumal, V., ... Latip, J. (2017). Antioxidant and antidiabetic effects of flavonoids: A structure-activity relationship based study. BioMed Research International, 2017. https://doi.org/10.1155/2017/8386065

Schreiber, S. B., Bozell, J. J., Hayes, D. G., \& Zivanovic, S. (2013). Introduction of primary antioxidant activity to chitosan for application as a multifunctional food packaging material. Food Hydrocolloids, $33(2)$, 207-214. https://doi.org/10.1016/j.foodhyd.2013.03. 006

Setyawan, A. D. W. I., \& Bermawie, N. (2014). Comparisons of isozyme diversity in local Java cardamom (Amomum compactum) and true cardamom (Elettaria cardamomum). Nusantara Bioscience, 6(1), 94-101. https://doi.org/10.13057/nusbiosci/n06011 5

Verma, A. K., Singh, H., Satyanarayana, M., Srivastava, S. P., Tiwari, P., Singh, A. B., ... Pratap, R. (2012). Flavone-based novel antidiabetic and antidyslipidemic agents. Journal of Medicinal Chemistry, 55(10), 4551-4567. https://doi.org/10.1021/jm201107g

Wang, T. yang, Li, Q., \& Bi, K. shun. (2018). Bioactive flavonoids in medicinal plants: Structure, activity and biological fate. Asian Journal of Pharmaceutical Sciences, 13(1), $12-23$. https://doi.org/10.1016/j.ajps.2017.08.004

Zhang, T. T., Lu, C. L., \& Jiang, J. G. (2014). Bioactivity evaluation of ingredients identified from the fruits of Amomum tsaoko Crevost et Lemaire, a Chinese spice. Food and Function, 5(8), 17471754. https://doi.org/10.1039/c4fo00169a

Zhang, T. T., Lu, C. L., \& Jiang, J. G. (2015). Antioxidant and anti-tumour evaluation of compounds identified from fruit of Amomum tsaoko Crevost et Lemaire. Journal of Functional Foods, 18, 423-431. https://doi.org/10.1016/j.jff.2015.08.005 